\title{
THE INFLUENCE OF CONTRIBUTION ACTIVITIES OF TURKEY ON ECONOMIC DEVELOPMENT OF COUNTRIES IN TRANSITION: THE CASE OF BOSNIA AND HERZEGOVINA AND KOSOVO ECONOMY
}

\author{
Suada A. Džogović ${ }^{1}$
}

\author{
Original scientific paper
}

Faculty of Business, University "Haxhi Zeka", Pejë/Peć, Republic of Kosovo

Received: 2019/2/28

Accepted: 2019/4/2

\begin{abstract}
The aim of this study is to improve the knowledge about the influence of the Republic of Turkey on the economic development of the Western Balkan countries in the period from 2003 to 2014. The analysis of the activities of the Republic of Turkey shows how much they contribute to the national product, that is, they had influence on the diversification of the economy, generate the income and sustainability of a part of the engaged population in Bosnia and Herzegovina and Kosovo. Comparative data of the analyzed countries show that, with oscillatory movements, an increase in total investments of the Republic of Turkey was recorded in the period from 2003 to 2014. From the analyzed period, it is clear that Turkey is pursuing an active economic policy, whose primary objective is to improve economic relations with the Western Balkan countries.
\end{abstract}

Keywords: Total Investments, Contribution Activities, Turkey, B\&H, Kosovo JEL Codes: F00, F59, O57, Z10, Z18

\section{INTRODUCTION}

In the last decade, Turkey's commitment to increasing political, economic and cultural influence on the Western Balkans has been markedly increased. All of this has resulted in discussions among politicians, scientists and journalists about the true goals of the Turkish government led by the Islamic-oriented, conservative AKP. Turkey has begun to apply a decisive diplomatic offensive in the Balkans since the Justice and Development Party (AKP) has been in power. In this direction, former Foreign Minister Ahmet Davutoglu has made a lot of efforts to help resolve the political stalemate in $\mathrm{B} \& \mathrm{H}$, offered mediation between
Kosovo and Serbia, and initiated various initiatives to resolve the existing problems between the countries in that region. In his opinion, the basis of the "political influence of the Republic of Turkey on Balchan are Muslim communities, the heirs of the failed Ottoman Empire" (Davutoglu, 2014, p. 134). In order to achieve its goals, Turkey must conduct a proactive policy in the Balkans regarding the problems concerning the future of Muslim communities in this region. As further emphasizes, in countries where Muslims - the natural allies of Turkey - in most (B\&H and Albania), the will appeared to turn this historical connection into a natural alliance (2014, p. 134), which the author considers to be Turkey's strategic interest.

\footnotetext{
${ }^{1}$ Correspondence to:

Suada A. Džogović, Faculty of Business, University "Haxhi Zeka", Pejë/Peć, Republic of Kosovo

Phone: +383(0)49441 141

E-mail: s.dzogovic@hotmail.com
} 
The growing Turkish influence, however, does not remain solely in the political field. With its growing economy, Turkey has become a magnet for people from the Balkans. Trade and tourism bloom, Turkish soap operas have become very popular on small screens in most Balkan countries, and Turkish universities have become an alternative to young people by offering them attractive scholarships. Jashari (2016) believe that Turkey's interest in the Western Balkans was constantly present in Turkish diplomacy, but also for the Balkan rulers, Ankara has always been a place of visiting and strengthening economic, political and military co-operation. However, the authors consider that the significant engagement of the Turkish film industry in the Western Balkan countries is present not only in places where the population is Islamic, but also in Croatia and Serbia (2016, p. 2).

But despite the positive, first of all economic aspects, many still look with suspicion on Turkey's new policy towards the Balkans. According to Erhan Türbedar, Balkan experts at the Turkish Foundation for Economic and Political Research (TEPAV), many people in the Western Balkans think that the main goal of the Turkish government is to strengthen ties with the Islamic world or that Turkey seeks to achieve its goal through cultural, political or economic funds. In his view, suspicion is based on the past, and the lack of information in the media on Turkish progress contributes to even more stereotypes (Simsek \& Martinovic, 2012). However, in order to suppress such attitudes, it is necessary at least to achieve a certain degree of historical objectivity. For example, in the foreword to his book, "Kosovo - A Short History," Noel Malcolm points out that his goal was not anti-Serbian but anti-myth. As further states, one day, all groups, that is, the Serbs, will have to reconcile themselves with their history (Malcolm, 1998: XXVII). Drawing on this and similar opinions, it should be emphasized that the analysis of Turkish foreign policy in the Western Balkan region requires a scientific approach rather than a conspicuous and xenophobic premise of some theoreticians whose academic engagement is related to certain political structures. For now, Turkish ambitions in the Balkans are limited by the fact that most of the Western Balkan population sees Turkey as a medieval occupier of these areas. Certainly, the Western Balkans is important for Turkish interests, but nevertheless significantly less than speculating in the public. In addition, it should be emphasized that Turkey has the economic potential to play a greater role in the Western Balkans, but at the same time is aware of the impossibility to undermine the influence of the EU in the current constellations.

\section{LITERATURE REVIEW}

There are two interpretations of the Turkish presence in the Balkans. Some analysts define Turkey as a country that pretends to be regional in power and constantly increases its economic power, while others believe that Turkey follows neo-Ottoman politics. In this context, arguments include historical and cultural links with the region, and the ambition of Turkey to perform independently of the West.

Former Prime Minister of the Republic of Turkey, Academician Ahmet Davutoğlu, in his book "Strategic Depth" (2001) states that Turkish influence in the Balkans is not neo -otthomanism. Due to its historical ties, geographical position and Islamic heritage, Turkey, in his view, has the right to actively act and design political, cultural and ethnic relations in the Balkans. In the same book Davutoglu puts emphasis on the Turkish potential of soft power based on active diplomatic efforts, regional cooperation and economic engagement in its many historical and cultural relations (Baran, 2010, p. 117). According to Davutoğlu, the new doctrine of Turkish foreign policy is a renewal of Turkish influence in areas that once represented a part of the Ottoman Empire. They divide Davutoğlu into three concentric geopolitical circuits. In the "inner circle", Kosovo, Albania and Macedonia, in the "central circle" are B\&H, Serbia, Greece and Bulgaria, while the "outer circle" is Croatia, Hungary and Romania. In addition, a strong Albania, a centralized B\&H and an independent Kosovo is extremely important for Turkey, because only this can confront the influence of other powers in the region.

However, Turkey's influence is not well accepted by Europe, as confirmed by Edward Said (1999). In his view, these relationships represent an academic problem. Namely, many authors consider Davutoğlu's book as the starting point for neo - ottomanism by promoting many strategies for improving relations with the Balkans and the Middle East. Similar opinion is represented by the deputy leader of the leading opposition Republican People's Party (CHP) Faruk Loğoglu who points out that the Balkan policy of the AKP government has two main dimensions. The first is neo-ottomanism, and the second dimension is the religion-based approach. Members of this party oppose such a strategy by advocating for an approach based on the principles and values of social democracy. However, Turkish politicians in power deny these allegations. In this context, Turkish diplomat Hasan Gogus tells DW that Turkey has built ties with the Balkan countries through a common history, and that claims on a hidden neo-ottomanism agenda are not true (Simsek \& Martinovic, 2012). 
Also, most analysts believe that the new foreign policy of the Republic of Turkey is based on this ideology. A specific assessment of the relations between Turkey and the Western Balkans was formulated by Dr. Nevenka Jeftić-Šarčević, who says that this region is a mutually contradictory and unintegrated area of the Balkans, which Turkey sees as a group of weakest links and the place in which it can best influence as a bearer of stability and progress (2010, p. 707) . She says she is prof. dr. Ahmet Davutoglu chose Sarajevo to present the components of his book, "Strategic Depth", because, in his opinion, Sarajevo is a miniature of Ottoman heritage and Ottoman civilization, as well as a prototype of the rise of the Balkans. Jeftić-Šarčević further concludes that it follows from this that $\mathrm{B} \& \mathrm{H}$ is one of the main strongholds on the way of returning Turkish influence to the Western Balkans (2010, p. 708). In this context, at the opening of the conference in Sarajevo entitled "The Ottoman Heritage and the Muslim Community of the Balkans Today", Davutoglu reminds that there are more Bosnians living in Turkey than in Bosnia and Albanians than in Albania, because, in his opinion, Ottoman heritage (Milos \& Landeka, 2009). According to the words of the late Turkish ambassador to Belgrade, Ahmet Umara, 9.5 million people live in Turkey from the Balkans (Rodić, 2010). The conference also said that Turkey will restore the Balkans, in an effort to make the new Balkan region based on political values, economic cooperation and cultural harmony (Milos \& Landeka, 2009). In other words, Davutoglu emphasizes that Turkey can no longer be a peripheral state whose political role is reduced to the bridge between civilizations, but must conduct an active foreign policy and become the center of cultural events and political decision-making.

In the book Strategic Depth (2014), in which all the more important assumptions of the new Turkish action on the international scene were elaborated in detail, prof. Davutoglu points to the importance of strengthening ties with the Western Balkans, the Middle East and Central Asia, and at the practical level advocates the establishment of a balance in relation to Turkish dependence on the West through the creation of more parallel alliances in the region. He also cites reasons for the importance of the Western Balkans for Turkey. In the first place, the Balkans region represents a geopolitical buffer zone (Buffer Zone) in the passage from Europe to Asia, from Asia to Europe, from the Baltic to the Mediterranean, and even to Africa, from the North to the South, from the East to the
West. At the same time, in his opinion, the Balkans is a region in the geoeconomic sense, as well as a region of geocultural interactions (Šćekić, 2013). According to Davutoglu, Turkey is a gifted country not only because of its geostrategic position and control of key sea routes and the sea, but also because of the historical heritage of the Ottoman Empire, which for centuries ruled large areas on the three continents in which it left its civilization traces.

The doctrine of neo-Mosmanism should have a positive connotation in the contemporary political and economic processes in the world, primarily in the Balkans. In political terms, it contains in its ideological etymony the political space of mutual respect and cooperation, provides opportunities for building its own political image synchronously exposed to the inter-European political project of communion and overcoming all the borders that nations have in the past divided, confronted and distanced from the general, cooperation and the building of a modern world on the planet, free from dictatorships, wars, genocide ... Therefore, Neo-Mosmanism should not be scared and propaganda launched against projects that modern Turkey affirms in the Balkans, the Middle East, the Caucasus ... They are motivated by the work of not conflicts of any kind. That "old" Ottomanism was civilization, while neo-Mosmanism in the EU could be a new, united, economic civilization at the level of global progress.

In concluding this review, we emphasize that societies and leaders interpret history in different ways. Perhaps the most dangerous thing is the conception of history as an obstacle to the future. In the view of academician Davutoglu, the Balkans has the potential to be a model of cultural coexistence that can become an example for other Europeans in resolving the issue of multiculturalism (Davutoglu, 2011). Therefore, historical reminiscences of the linking of the Balkan states of Islamic features cannot be in the function of science, and Turkey will surely additionally strengthen the economic role in B\&H, in Kosovo, and in the Balkans in general.

In support of the fact that the new Turkish foreign policy in the Western Balkans can primarily be motivated by economic interests, in the continuation of this study, we present the results of Turkey's weightbearing influence on the cultural sector in the national economy of B\&H and the Republic of Kosovo for a period of ten years (2003-2014). In concluding this review, we emphasize that societies and leaders that interpret history in different ways. 


\section{EMPIRICAL DATA AND METHODOLOGY}

The influence of the Republic of Turkey on the cultural sector, as well as the impact on the economic development of Bosnia and Herzegovina ${ }^{2}$, i.e. the Republic of Kosovo, contribute to the gross domestic product. The indicator assesses the weight of the Republic of Turkey on the cultural sector in the national economy by comparing the investments of the Republic of Turkey, which include activities for creation, production and distribution of cultural activities, goods and services, as well as the GDP of both countries. The analysis of the activities shows how much they contribute to the national product, i.e. the impact on the diversification of the economy, revenue generation and the sustainability of the part of the engaged population.

The data used to assess the activities of the Republic of Turkey that have contributed to the economic development of $\mathrm{B} \& \mathrm{H}$ and the Republic of Kosovo are:

- World Development Indicators; data downloaded from the website: http://databank.worldbank.org/

- Organization for Economic Co-Operation and Development, OECD. Statistic data downloaded from the website: http://stats.oecd.org/
Based on the collected data, we compare the total gross value added (GVA) and gross domestic product (GDP), thus providing the opportunity to determine the contribution of cultural activities to the national $\mathrm{GDP}^{3}$.

$$
\% C_{T R} G D P=\frac{\sum_{i}^{n} G V A_{i}}{G D P}
$$

$\%$ CTRGDP percentage of the contribution of the cultural activities of the Republic of Turkey in comparison with GDP

GVA total investments of the Republic of Turkey in cultural sector

GDP gross domestic product

\section{Activities contributed to economic development of B\&H}

\section{Gross domestic product and the impact of coopera- tion with Turkey}

From the data presented for the B\&H Gross Domestic Product, in the period from 2003 to 2014, it can be concluded that with oscillatory movements an increase of US \$ 8 million was recorded in 2003 to US \$ 18 million in 2014, an increase by 2.2 times (Graph 1).

\section{GDP of Bosnia and Hezcegovina}

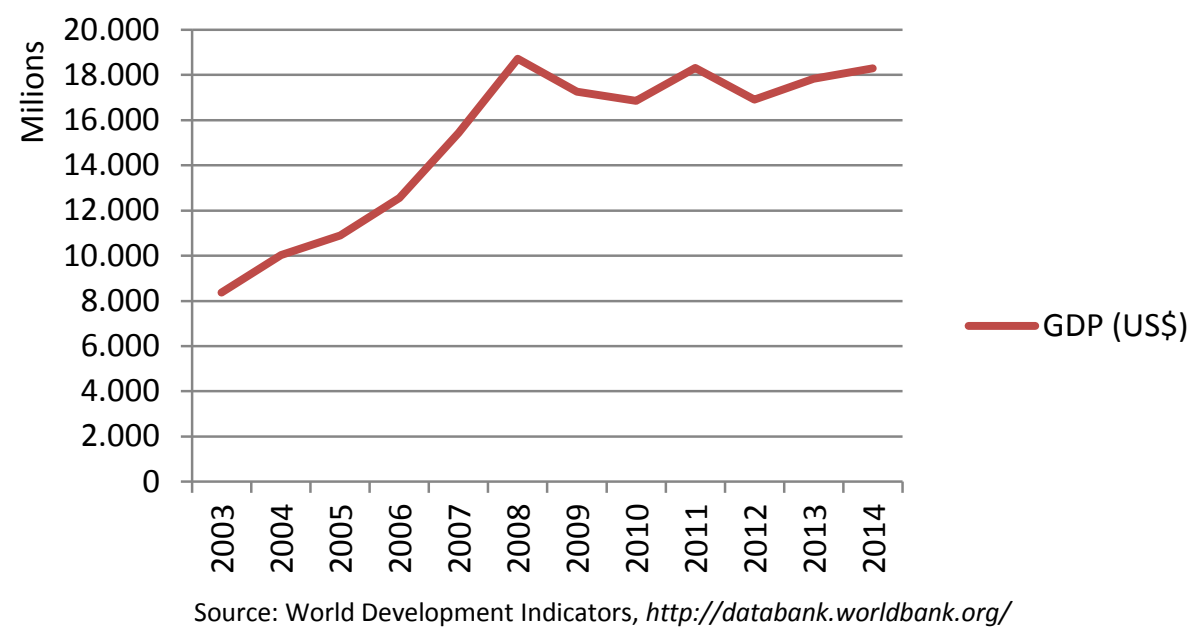

Graph 1. Graphic presentation of B\&H GDP in the period 2003-2014

\section{Bilateral assistance from the countries of $D A C$}

According to the available data on the bilateral donor assistance from DAC in $\mathrm{B} \& \mathrm{H}$ in the period between 2003 and 2013, it can be concluded that from 2003 to 2010 the value of the bilateral assistance from the DAC countries was reduced from 480 million US \$ in 2003 to 380 million US \$ in 2010. In 2011, the value of bilateral aid was increased to 580 million, to be again reduced to US \$ 500 million (Graph 2).
${ }^{3}$ UNESCO Culture for Development Indicators, Methodology Manual, ISBN 978-92-3-001227-4. Data downloaded from the web-side: https://en.unesco.org/creativity/sites/creativity/files/ digital-library/CDIS\%20Methodology\%20Manual_0.pdf (insight: 10/01/2016). 
DAC donations for Bosnia and Herzegovina

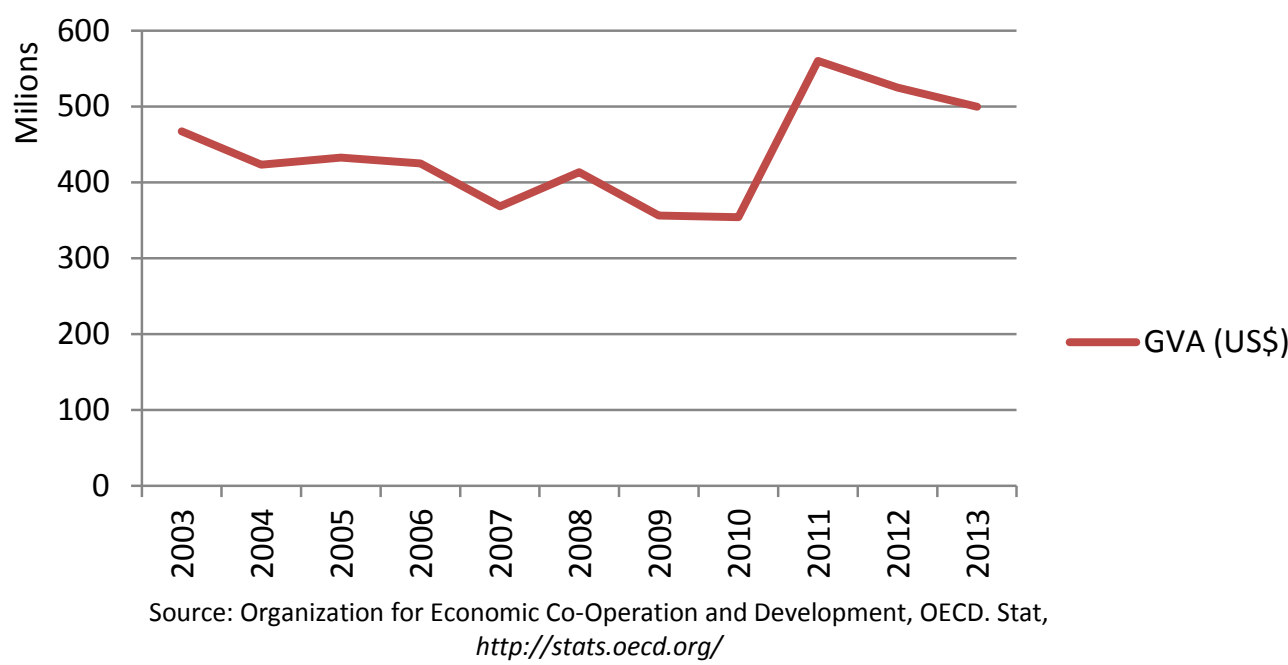

Graph 2. Graphic presentation of donations from DAC funds for B\&H in the period 2003-2013

Investments of the Republic of Turkey

In the period from 2003 to 2014, in B\&H there was an increase in the gross investments of the Republic of Turkey, with oscillatory movements. In 2004, they amounted to US \$ 5 million, in 2006 US \$ 25 million, in 2009 US \$ 32 million, while in 2014 they amounted to US \$ 44 million (Graph 3).

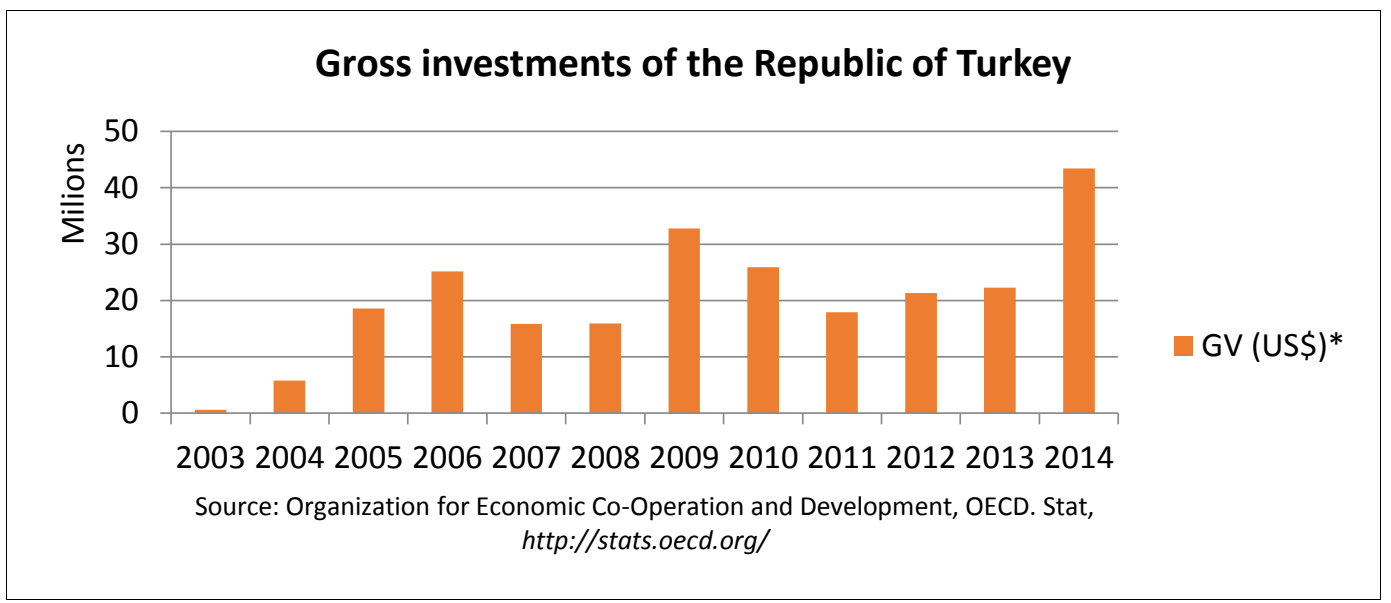

Graph 3. Graphic presentation of the gross investments of the Republic of Turkey in B\&H in the period 2003-2014

\section{Investments in the sector culture}

In the period from 2005 to 2013 , the highest investments in the Bosnian-Herzegovinian sector of culture were recorded in 2009 in the amount of US \$ 20 million. After that, investments are declining. In 2010, they amounted to US \$ 13 million, and in 2013 US \$ 3 million (Graph 4).

\section{Gross Investments in cultural activities}

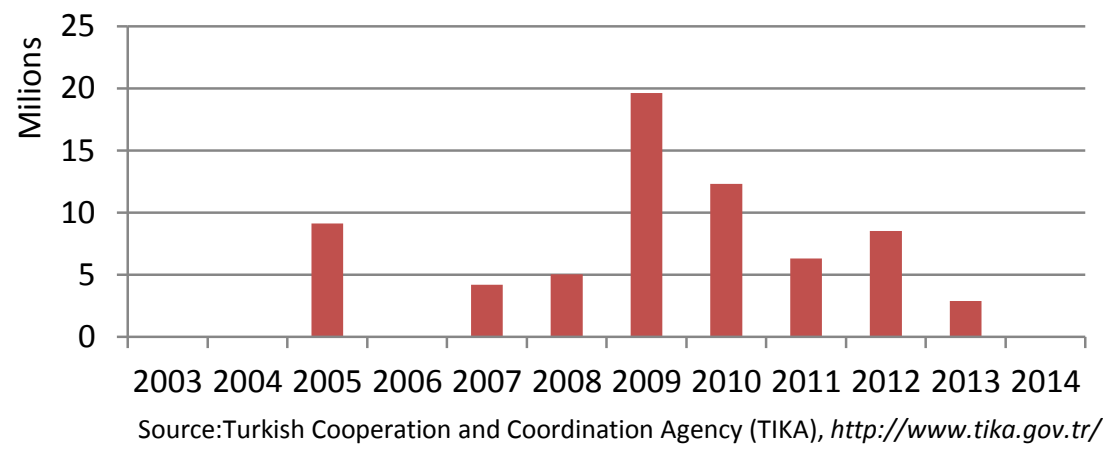

Graph 4. Graphic presentation of the investments in the sector culture of the Republic of Turkey in B\&H in the period 2003-2014 
In the period from 2005 to 2013, the highest investments in the Bosnian-Herzegovinian sector of culture $(\mathrm{GVA} \%)$, compared to other investments, were re- corded in 2009, when they amounted to $60 \%$. After that, there was a decline and in 2013 they amounted to $13 \%$ (Graph 5).
2005

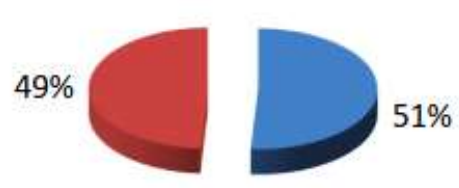

- OTHER\% GVA\% (\%)*
2007

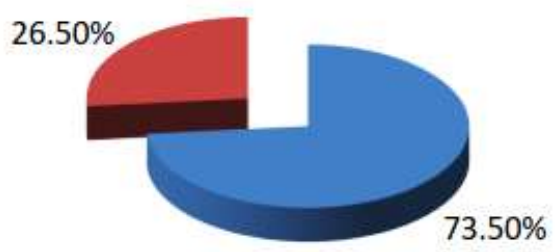

-
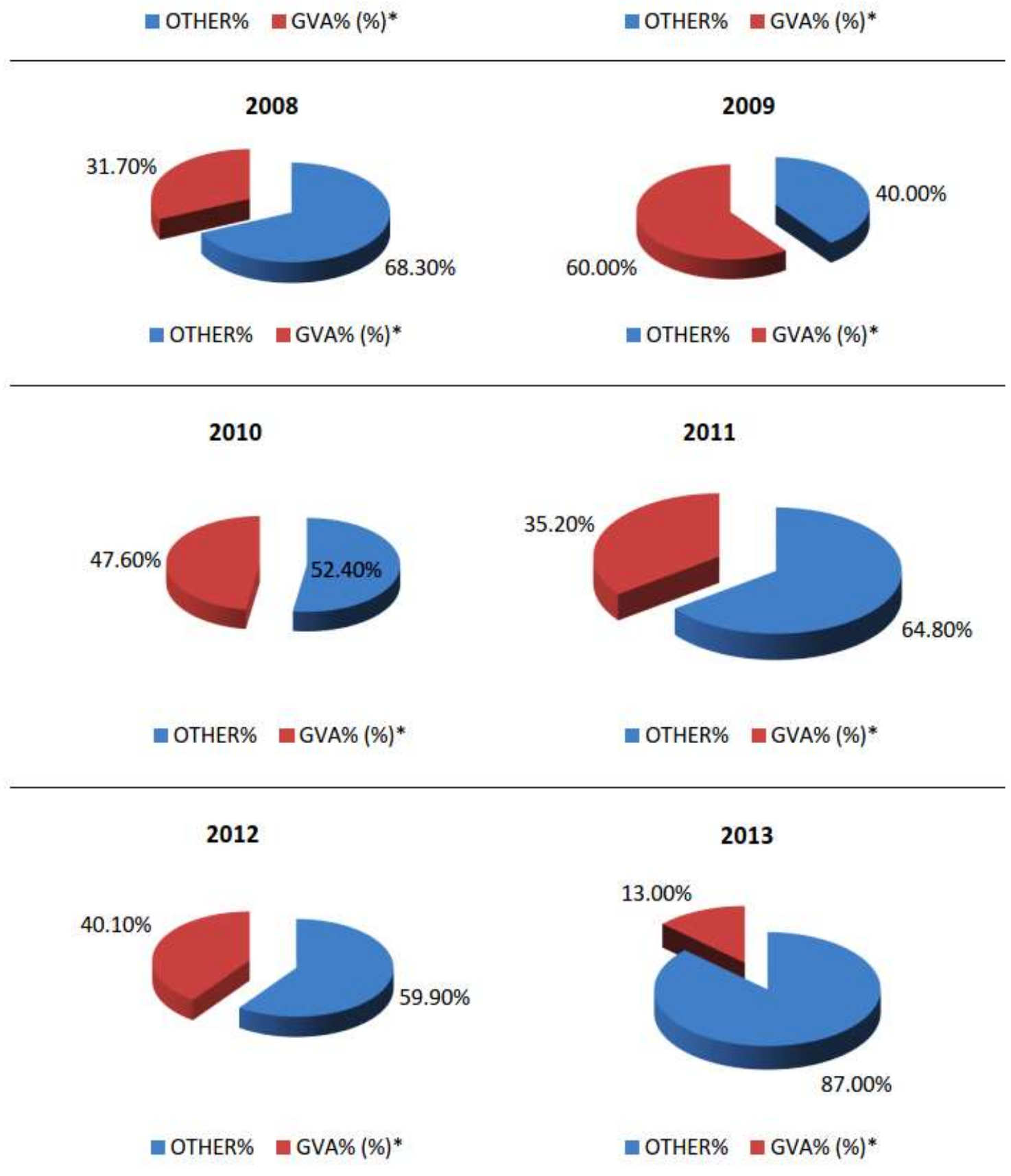

Graph 5. Graphic presentation of the investments GVA\% of the Republic of Turkey in $B \& H$ in terms of total investments in the period 2005-2009 
Percentage overview of the contribution of the Republic of Turkey to cultural activities

The contribution of the Republic of Turkey to the Bosnian-Herzegovinian culture sector for the period 2005-2013 is graphically presented (Graph 6, Graph

7). Through the analysis of the data from the graph, it can be concluded that in the period from 2005 to 2008 , the influence of the Republic of Turkey on cultural activities from $0.08 \%$ in 2005 to $0.03 \%$ in 2008 was reduced. In 2009, an increase of $0.11 \%$ was observed, when the highest value was observed. After that, there is a decline, so in 2013 it amounted $0.02 \%$

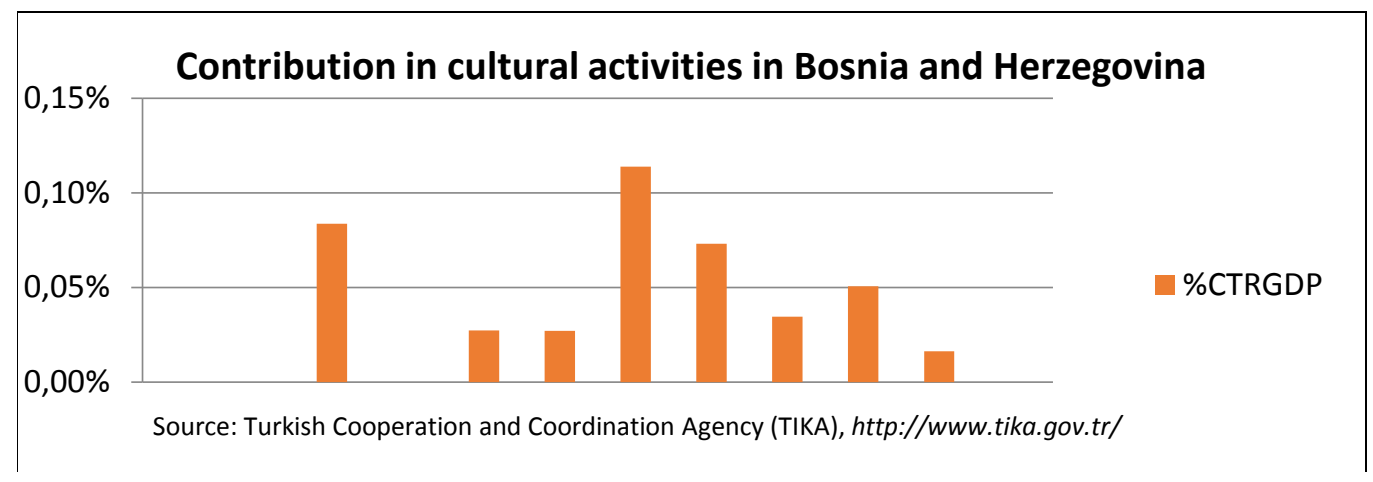

Graph 6. Graphic representation of the contribution of the Republic of Turkey to cultural activities of $B \& H$

2005
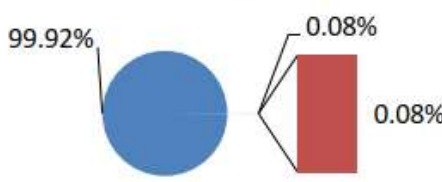

GDP (\%) $\%$ CTRGDP
2007

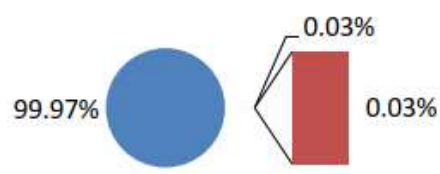

aDP $(\%) \quad$ aCTRGDP

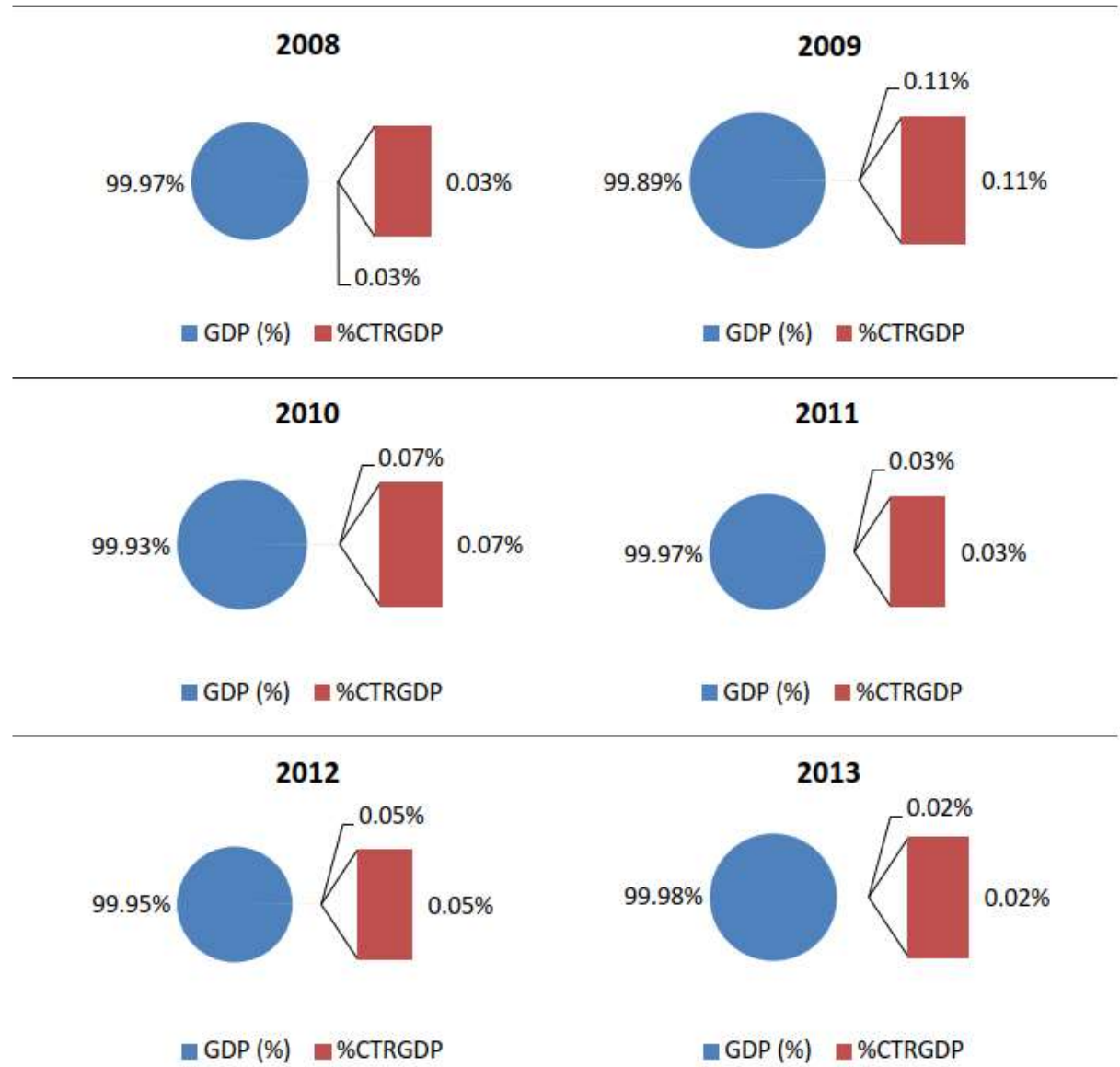

Graph 7. Contribution of the Republic of Turkey to the overall cultural activities of B\&H in the period 2005-2013 
Contribution activities on economic development of the Republic of Kosovo Gross domestic product and the impact of the coop- increase of 2.2 times (Graph 8).
In the period from 2003 to 2013, Kosovo has recorded a continuous increase in GDP, from US \$ 3.3 million in 2003 to US \$ 7.3 million in 2014, which is an eration with Turkey

GDP OF THE REPUBLIC OF KOSOVO

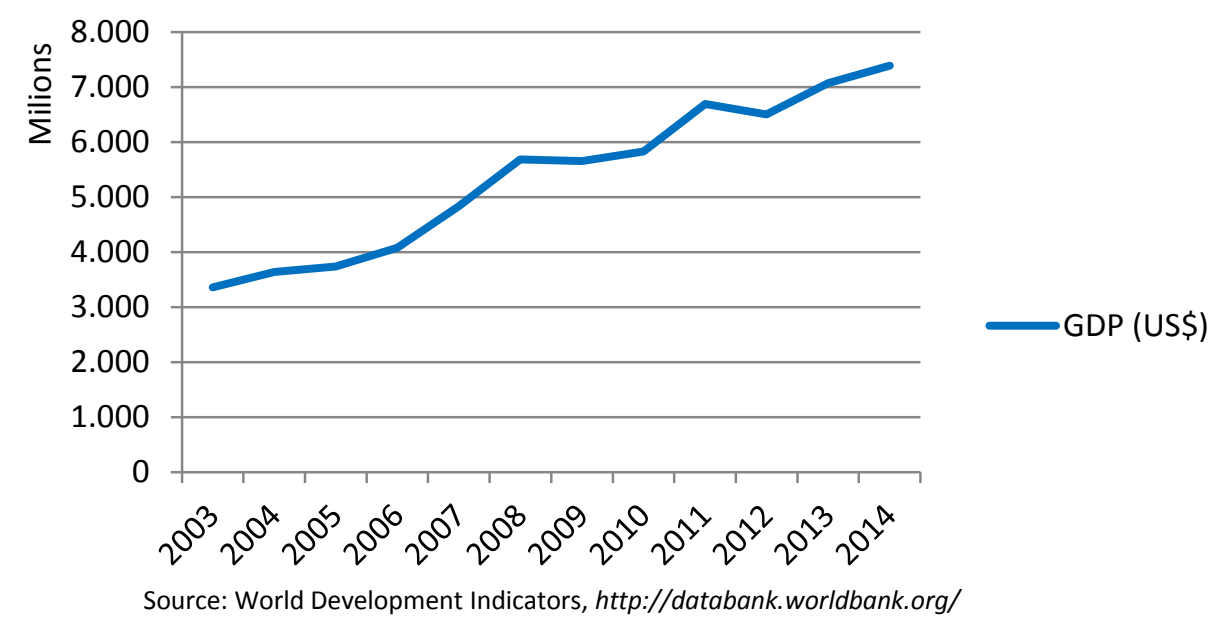

Graph 8. Presentation of the GDP of the Republic of Kosovo in the period 2003-2014

\section{Bilateral help from DAK donors}

In the period 2009-2013, the bilateral assistance to the
DAC countries in the Republic of Kosovo has been reduced from US \$ 750 million in 2009 to US \$ 490 million in 2013 (Graph 9).

\section{GDP OF THE REPUBLIC OF KOSOVO}

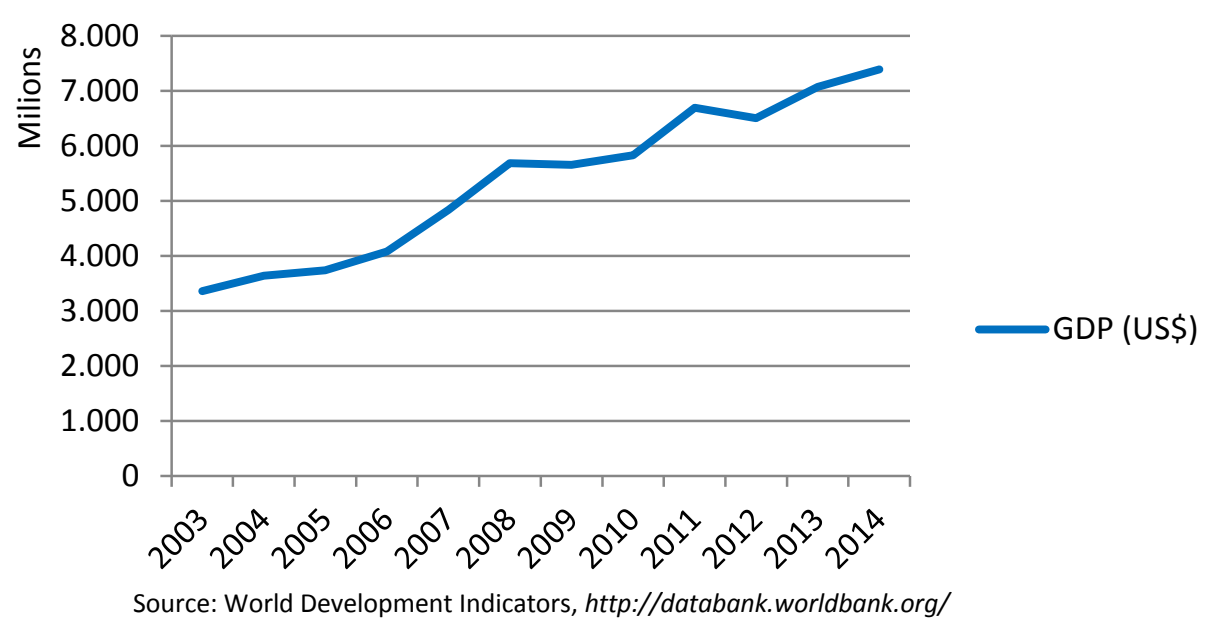

Graph 9. Graphic presentation of the donations of the DAC funds for the Republic of Kosovo in the period 2003-2013

\section{Investments of the Republic of Turkey}

In the Republic of Kosovo, in the period from 2009 to 2014, the total investments of the Republic of Turkey are increased from US \$ 20 million in 2009 to US \$ 23 million in 2011. However, in 2013, there was a decline in investments of US \$ 15 million, while in 2014 there was again an increase of US \$ 17 million (Graph 10). 


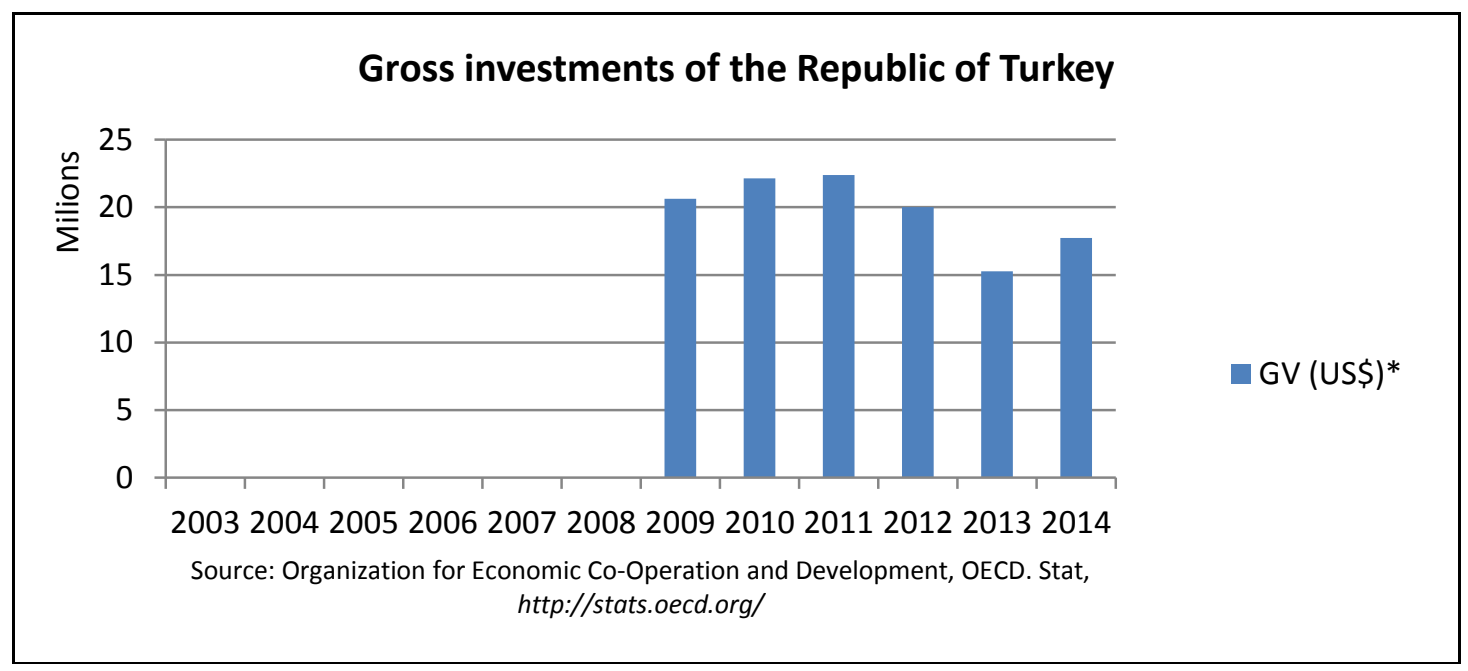

Graph 10. Graphic presentation of the gross investments of the Republic of Turkey in the Republic of Kosovo in the period 2009-2014

\section{Investments in the sector of culture}

In the period from 2009 to 2013, the Kosovo cultural sector saw high investments in 2009 when it amount- ed to US \$ 12 million. After that, investments are declining. In 2010, it was US \$ 10 million, in 2012 US \$ 8 million, while in 2013 it was US \$ 2 million (Graph $11)$.

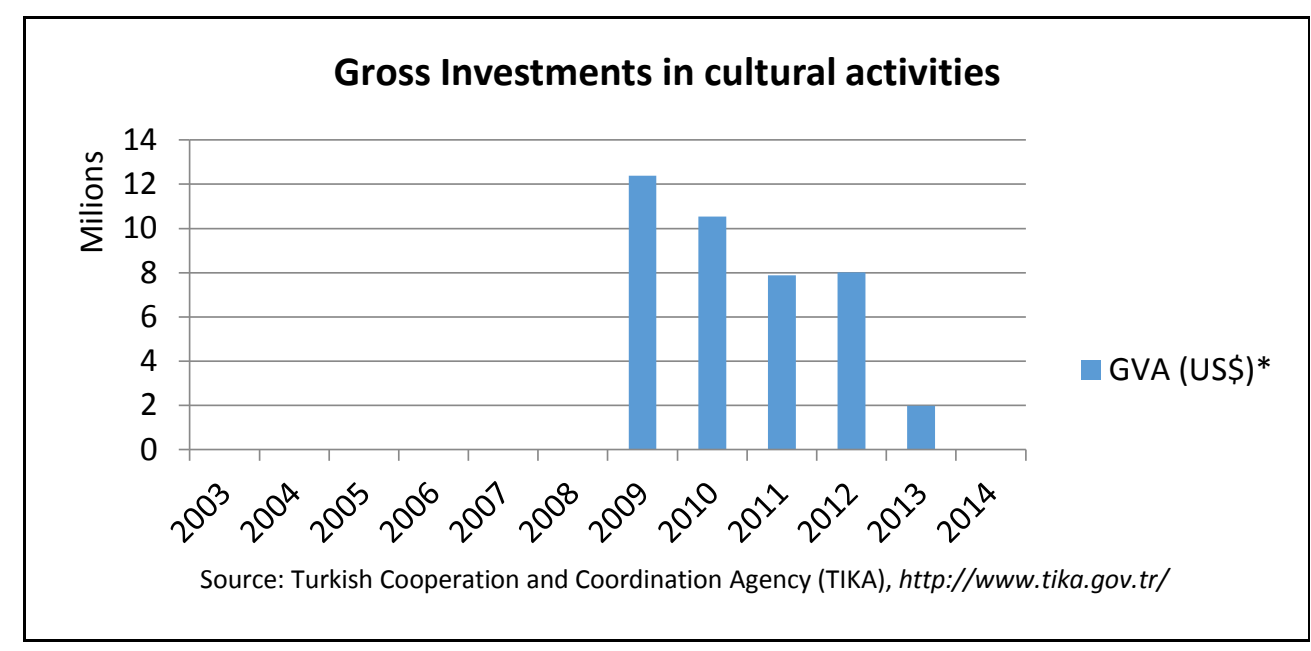

Graph 11. Graphic presentation of the sectoral investments of the Republic of Turkey in the Republic of Kosovo in the period 2009-2013

In the period from 2009 to 2013, the highest investments ments, were registered in 2009 when they amounted to in the culture sector (GVA\%), compared to other invest- $\quad 60 \%$, while in 2013 they were 13\% (Graph 12). 


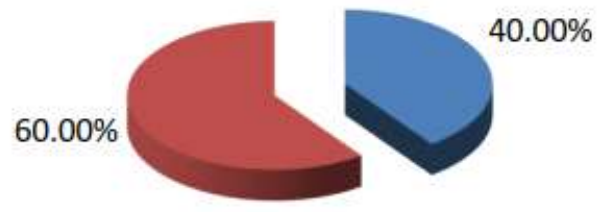

OTHER \% GVA\%

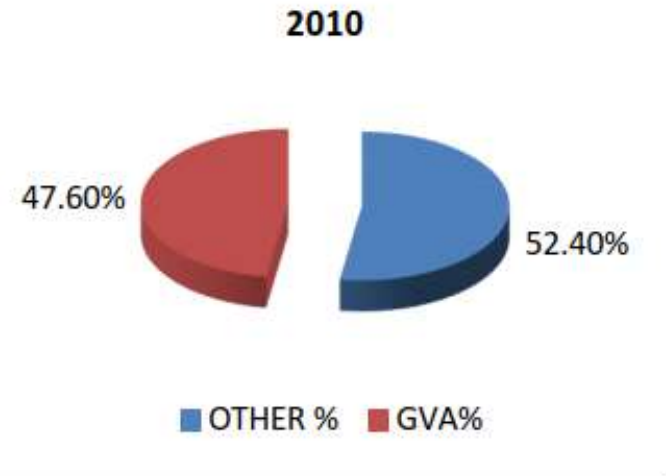

2012

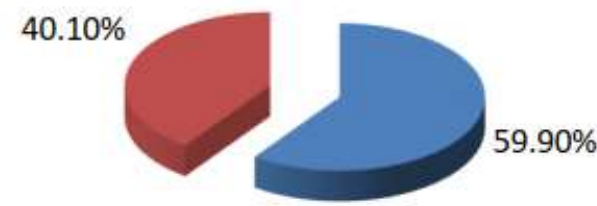

—OTHER \% GVA\%

2013

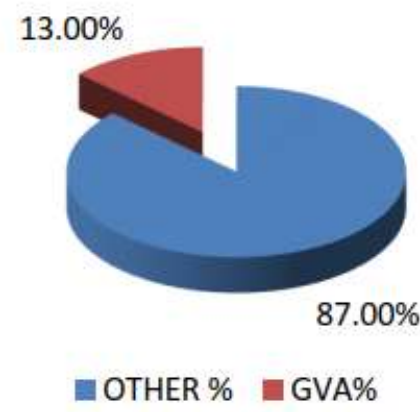

Graph 12. Graphic presentation of the sectoral investments GVA\% of the Republic of Turkey in the Republic of Kosovo in relation to the total investments in the period 2009-2013

Percentage overview of the contribution of the Re- lic of Kosovo in the period from 2009 to 2013 is shown public of Turkey in cultural activities graphically (Graph 13, Graph 14). Through the analysis of the data, it can be concluded that a decrease of

The contribution to the cultural activities of the Repub- $\quad 0.22 \%$ in 2009 was registered at $0.03 \%$ in 2013 .

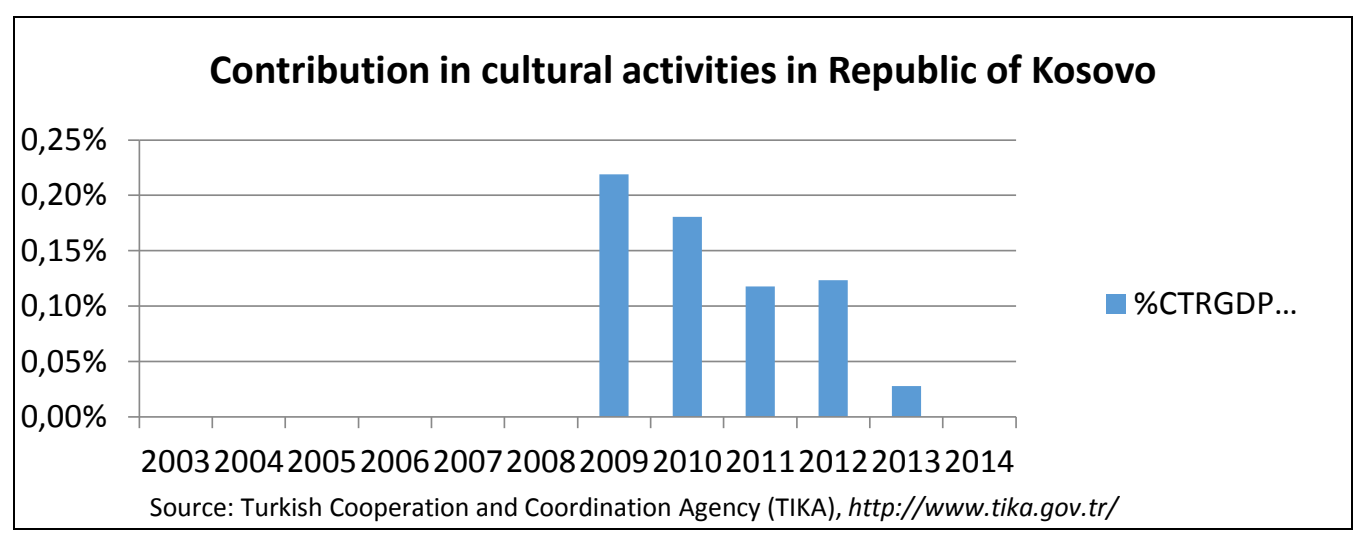

Graph 13. Graphic presentation of the contribution of the Republic of Turkey in the cultural activities of the Republic of Kosovo in the period 2009-2013 
2009

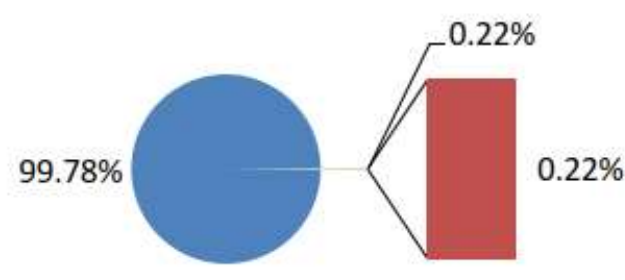

GDP (\%) $\quad \%$ CTRGDP (\%)

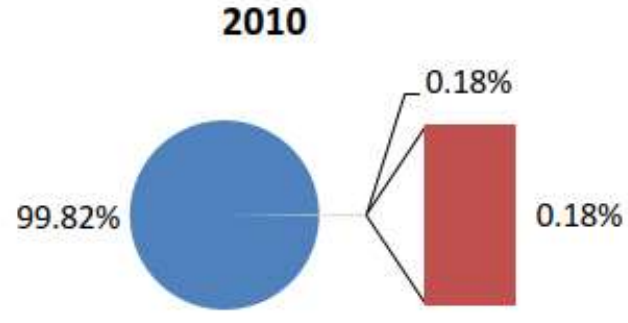

aDP $(\%) \quad \% C T R G D P(\%)$
2011

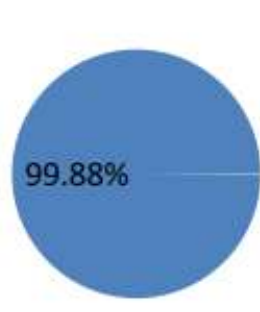

aDP $(\%) \quad$ aCTRGDP (\%)
2012

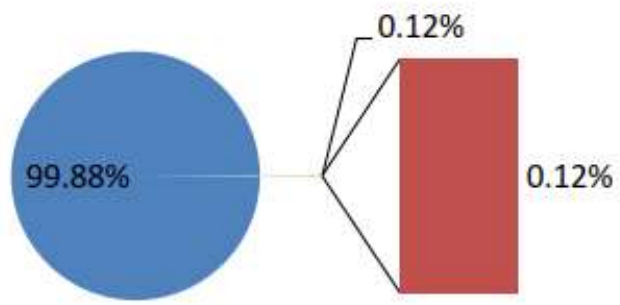

- GDP (\%) $\quad$ \%CTRGDP (\%)

2013

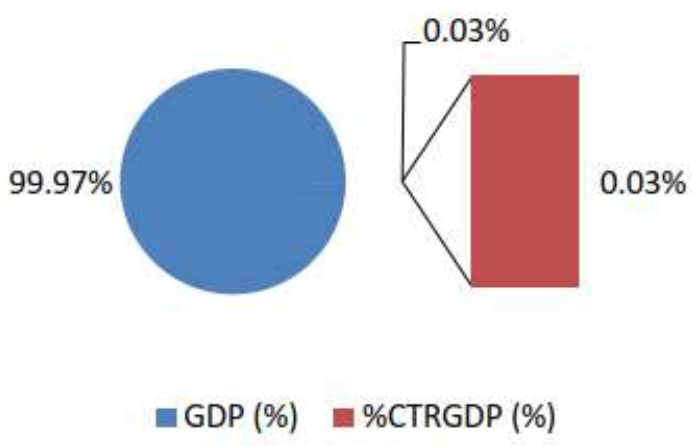

Graph 14. Contribution of the Republic of Turkey to the overall cultural activities of the Republic of Kosovo in the period 2009-2013

RESEARCH FINDING AND DISCUSSIONS

\section{Gross Domestic Product (GDP)}

GDP is the sum of the gross value added of all resident producers in the economy plus all product taxes, then reduced for all subsidies that are not included in the value of the product. It is calculated without deductions for the depreciation of the produced property, for the impoverishment, i.e. for the destruction of natural resources. The data are expressed in US dollars. GDP is calculated by converting the official exchange rates of domestic currencies and the US dollar over a one-year period.

Comparison of GDP data in B\&H and in the Republic of Kosovo is shown graphically (Graph 15). Through the analysis of the data from the graph, it can be concluded that in the period from 2003 to 2014, with oscillatory movements, B\&H has seen GDP growth from US \$ 8.3 million in 2003 to US \$ 18 million in 2014 , or by 2.2 times. In the same period in Kosovo, a continuous GDP growth of 3.3 million US \$ in 2003 was registered to 7.3 million US $\$$ in 2014, which is also 2.2 times higher. 


\section{Gross Domestic Product (US\$)}

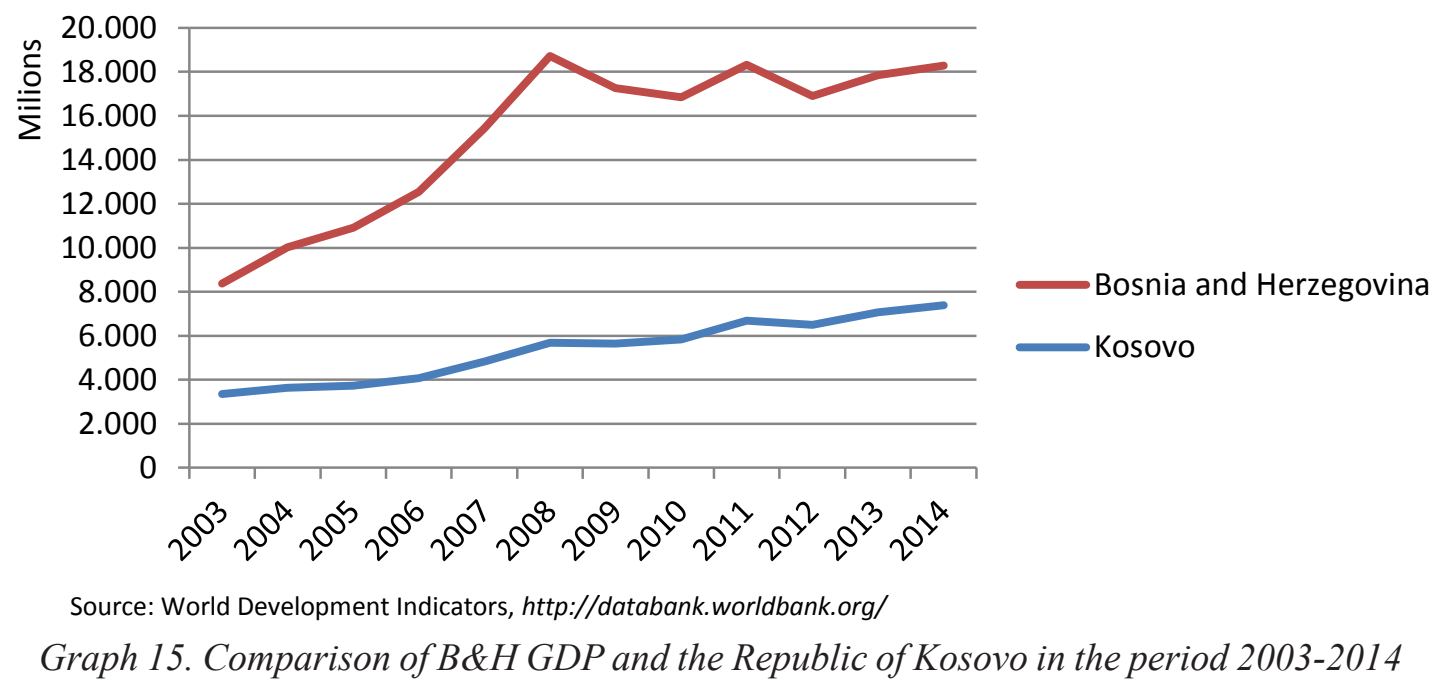

\section{Bilateral help from donors of DAC}

The net bilateral aid flows from the donors of DAC are net payments for ODA or the official developmental assistance of the members of the Development Assistance Committee (DAC). Net payments are gross leverage payments and loans less repayment of the principal of previous loans. ODA consists of loans concluded under privileged terms (with a grant of at least $25 \%$, calculated at a rate at a discount of $10 \%$ ) and subsidies made for the promotion of economic development and welfare in the countries and territories of the recipient's list of DAC and ODA. The official support refers to the support of the official donors of countries and territories in Part II of the Census of DAC recipients: advanced countries of Central and Eastern Europe, countries of the former Soviet Union, as well as certain advanced countries in terms of development and territories. Official assistance is provided under conditions similar to those for ODA. Members of DAK are the following countries: Australia,
Austria, Belgium, Canada, Czech Republic, Denmark, Finland, France, Germany, Greece, Iceland, Ireland, Italy, Japan, the Republic of Korea, Luxembourg, the Netherlands, New Zealand, Poland, Portugal, Slovakia, Spain, Sweden, Switzerland, United Kingdom, United States of America, and the institutions of the European Union. The data presented are in US dollars.

By analyzing the data (Graph 16), comparative data on the bilateral assistance of the DAC countries for B\&H and the Republic of Kosovo are shown, based on which it can be concluded that in B \& H, in the period from 2003 to 2010 , the value of bilateral assistance in DAC countries have been reduced from $\$ 480$ million in 2003 to $\$ 380$ million in 2010. In 2011, the value of bilateral aid increased to $\$ 580$ million, to be again reduced in 2013 to $\$ 500$ million. In the Republic of Kosovo, in the period from 2009 to 2013, bilateral assistance to the DAC countries has also been reduced from 750 million in 2009 to 490 million US dollars in 2013.

\section{DAC donations}

(US\$)

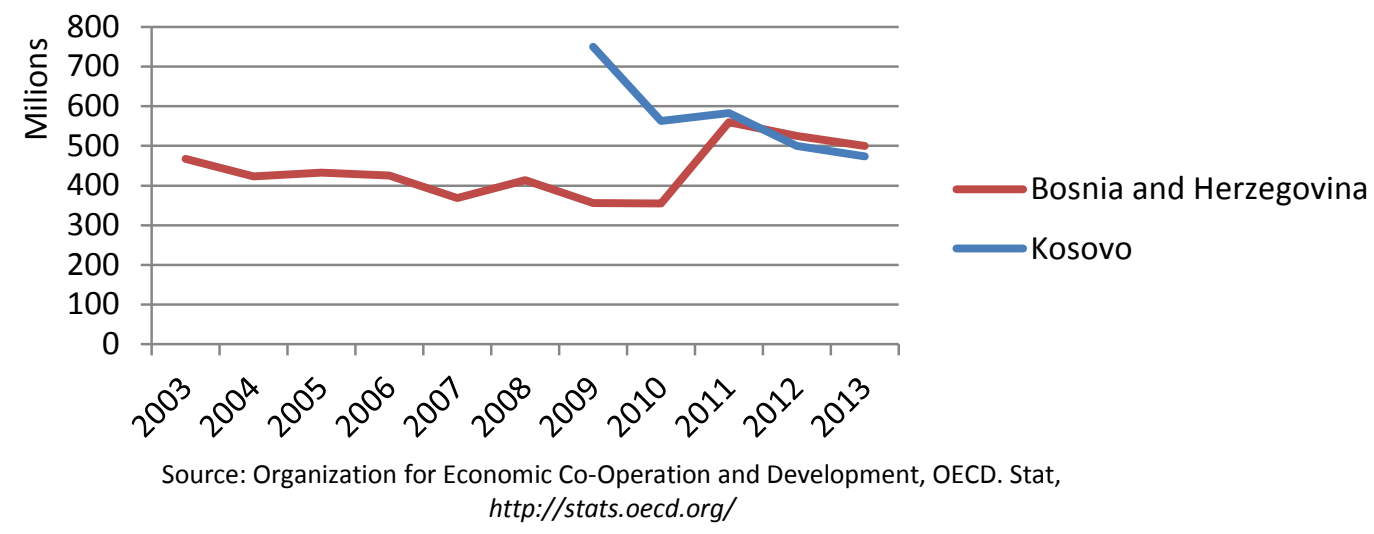

Graph 16. Comparison of the bilateral assistance of the DAC countries for $B \& H$ and the Republic of Kosovo in the period 2003-2013 


\section{Investments of the Republic of Turkey}

According to the analysis of the comparative data, the total investments in B\&H and the Republic of Kosovo in the period from 2003 to 2014 (Graph 17) can be concluded that in $\mathrm{B} \& \mathrm{H}$, with oscillatory movements, an increase in the total investments was registered. In 2004 they amounted to US \$ 5 million, in 2006 US \$
25 million, in 2009 US \$ 32 million, while in 2014 they amounted to US \$ 44 million.

In the Republic of Kosovo, in the period 2009 to 2014, the total investments of the Republic of Turkey increased from US \$ 20 million in 2009 to US \$ 23 million in 2011. However, in 2013, there was a decline in investments of US \$ 15 million, while in 2014 there was an increase of $\$ 17$ million again.

Total investments of the Republic of Turkey (US\$)

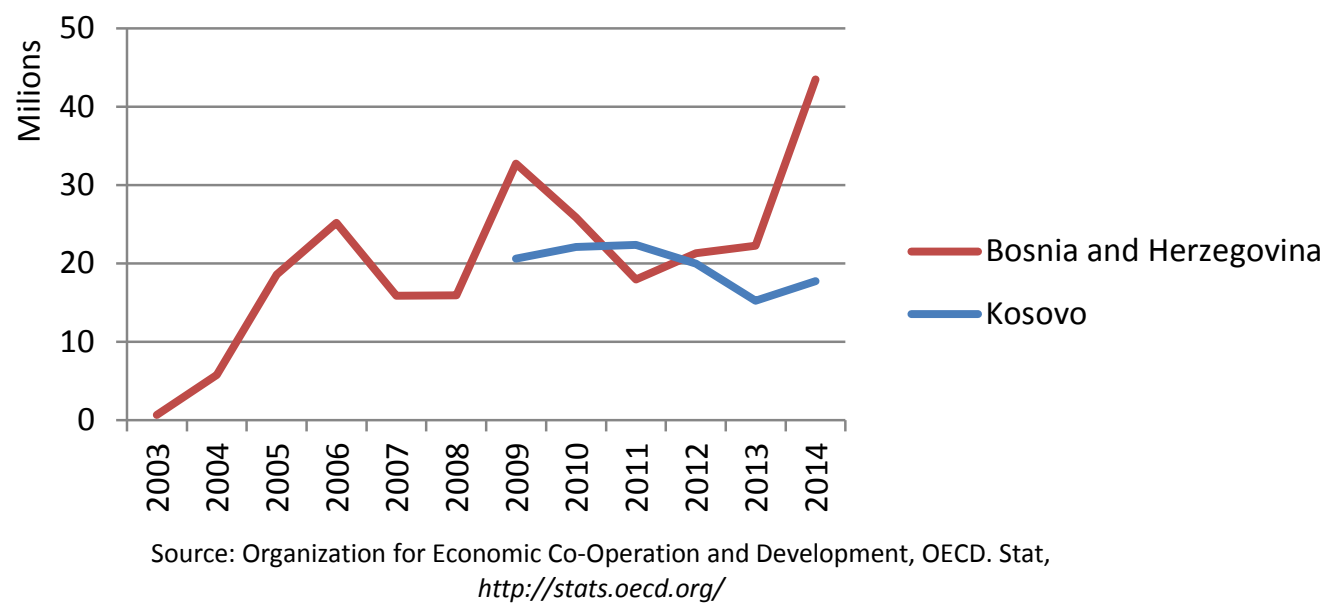

Graph 17. Comparison of the total investments of the Republic of Turkey in $B \& H$ and in the Republic of Kosovo in the period 2003-2014

\section{Investments in the sector for culture}

In the period from 2003 to 2013 , the highest investments in the cultural sector were recorded in 2009 in the amount of US \$20 million. After that, the invest- ments declined and in 2013 amount to US \$ 3 million. In the Republic of Kosovo, in the period from 2009 to 2013 , the investments were also reduced by $\$ 12$ million, which amounted to 2 million in 2013 in 2009 (Graph 18).

Total investments of the Republic of Turkey in the cultural activities (US\$)

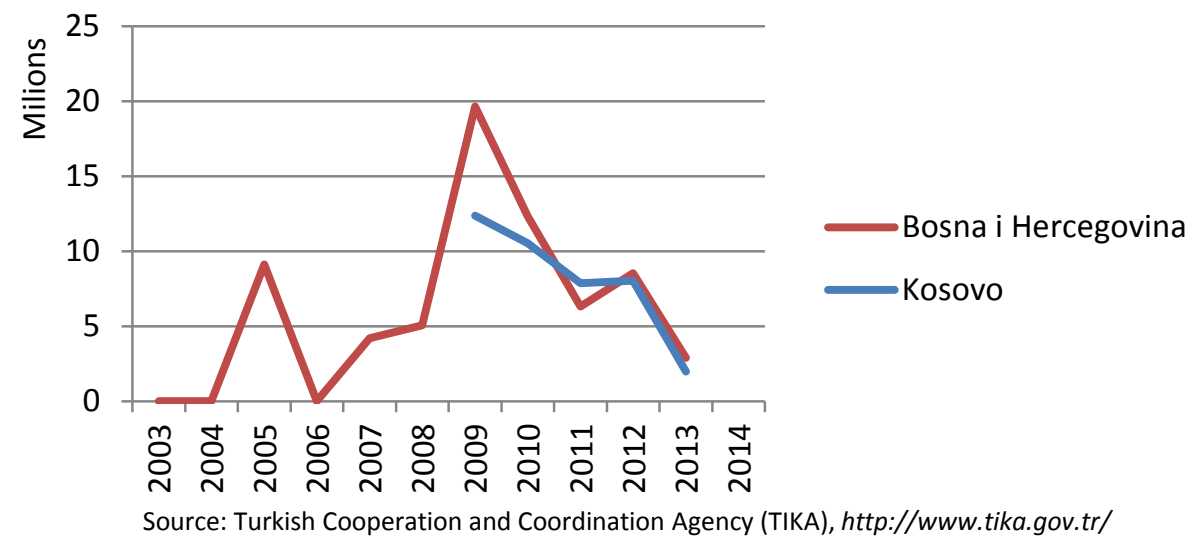

Graph 18. Comparison of the total investments of the Republic of Turkey in the cultural activities of B\&H and the Republic of Kosovo in the period 2003-2013 


\section{CONCLUSION}

The disintegration of the SFR of Yugoslavia, which once partially entered the composition of the Ottoman territory, intensified the activities of the Republic of Turkey for a more active presence in the countries that emerged from it. Primarily, the impact is economic and cultural, but the tendency of general geopolitical influence cannot be neglected, because it is one of the most important Eurasian states that NATO needs as a member of the NATO alliance, since the main gas pipelines and oil pipelines will pass through Turkey. Societies and leaders interpret history in different ways, but it turns out that the wrong perception of the past should not be an obstacle for a healthy conception of relations in the future. Historical reminiscences about the linking of the Balkan states of Islamic features cannot be in the function of science, and Turkey will definitely further strengthen its role in $\mathrm{B} \& \mathrm{H}$, in Kosovo and in the Balkans in general.

In addition to the efforts of the West and Russia in order to intensify political and economic power in the Balkans, Turkey's efforts to keep if not flaunt their influence are also lagging behind. If Turkey were not to become a member of the Union, in that case, Bosnia and Herzegovina and Kosovo would become the most western points of the anti-war populations, and could serve as an EU entry, given that these countries can enter the Western Balkans region smoothly and with that in the EU.

Encouraged by numerous qualities, especially economic growth, Turkey has many landmarks that have been enhanced by very high economic growth and economic growth. These are the reasons that, in its foreign policy, it will not allow the peripheral country to remain in the context of EU integration. The opinion of certain authors that Turkey is a "poor country" is not based on expert analysis. Such an interpretation makes it difficult to get to know the real development dynamics and the political idea about it. Namely, despite the global economic crisis, internal turmoil and terrorism problems, Turkey has recorded remarkable economic progress and attracted special attention of world power centers.

\section{REFERENCES}

Baran, Z. (2010). Torn Country: Turkey between Secularism and Islamism, Hoover Institute Press.

Davutoğlu, A. (2011). A Forward Looking Vision for the Balkans, SAM Vision Papers, No. 1, p. 8. Source: http://sam. gov.tr/wp-content/uploads/2012/01/vision paperen1.pdf (insight: 15/10/2014).

Davutoglu, A. (2014). Strategijske dubine, Beograd, 1-500.

http://databank.worldbank.org/.

http://stats.oecd.org/.

Jashari, H. (2017). Socio-Cultural Influence of Turkey and its Relations with the Western Balkans. Journal of Humanities, Culture and Social Sciences, 3(1), pp. 15-22. http:// www.journal.faaa.ro/wp-content/uploads/2017/06/31-Jashari.pdf (insight: 09/01/2018).

Jeftić-Šarčević, N. (2010). Zapadni Balkan u 'Turskoj strateškoj viziji', MP 4, pp. 691-714. Source: http://www.doiserbia. nb.rs/img/doi/0025-8555/2010/0025-8555100 4691J.pdf (insight: 15/10/2014).

Malcolm, N. (1998). Kosovo - A Short History, London, Macmillan, p. XXVII.

Miloš, P. i Landeka M. (2009). Turski ministar u Sarajevu: Obnovit ćemo otomanski imperij na Balkanu, Slobodna Dalmacija (27/10/2009). Source: https://www.slobodnadalmacija.hr/ novosti/bih/clanak/id/73393/turski-ministar-u-sarajevu-obnovit-cemo-otomanski-imperij-nabalkanu (insight: 15/10/2014).

Rodić, F. Povratak starih prijatelja, Tanjug (04/03/2010). Source: http://www.standard.rs/ (insight: 29/11/2016).

Said, E. W. (1999). Orijentalizam (Translated from English by: Rešid Hafizović), Svjetlost, Sarajevo.

Simsek, A. i Martinović, M. (2012). Turska na Balkanu: mitovi, iluzije i stvarnost, Deutsche Welle (22/05/2012). Source: http://www.dw.com/bs/turska-na-balkanu-mitovi-iluzijei-stvarnost/a-15956765 (insight: 09/05/2016).

Šćekić, R. (2013). Balkan kao prostor prožimanja civilizacijskih uticaja u svijetlu neoosmanističkog koncepta, OSVIT, Glas Muslimana Crne Gore (Časopis za kulturu, nauku i društvena pitanja Muslimana Crne Gore), year IV, No 5, Podgorica, pp. 70-71. Source: http://www.maticamuslimanska.me/wp-content/uploads/2013/10/Kolori -zaIstoriju-Muslimana.pdf (insight: 19/09/2014).

UNESCO Culture for Development Indicators, Methodology Manual, ISBN 978-92-3-001227-4. Data taken from web-page: http://en.unesco.org/creativity/sites/creativity/files/ digital-library/CDIS\%20 Methodology $\% 20$ Manual_0.pdf (insight: 10/01/2016). 